\title{
Deterrent Punishment and Respect for Persons
}

\author{
Zachary Hoskins*
}

This article defends deterrence as an aim of punishment. Specifically, I contend that a system of punishment aimed at deterrence (with constraints to prohibit punishing the innocent or excessively punishing the guilty) is consistent with the liberal principle of respect for offenders as autonomous moral persons. I consider three versions of the objection that deterrent punishment fails to respect offenders. The first version, raised by Jeffrie Murphy and others, charges that deterrent punishment uses offenders as mere means to securing the social good of crime reduction. The second and third are developed by R.A. Duff. The second holds that deterrent punishment inappropriately excludes offenders from the moral community. The third charges that deterrent punishment offers community members the wrong sorts of reasons to comply with the law. I conclude that each of these objections fails. A system of punishment aimed at deterrence (suitably constrained) is consistent with respect for offenders as moral persons.

\section{INTRODUCTION}

Deterrence-based accounts of punishment have been criticized frequently because they are unable to rule out occasionally punishing innocent citizens, or disproportionately punishing guilty ones, if doing so would yield net deterrent benefits. ${ }^{1}$ In response to these sorts of objections, some theorists have argued that although considerations of deterrence cannot ground a complete justification of punishment, they may nevertheless shoulder some of the justificatory burden. Perhaps most notably, H.L.A. Hart contended that consequentialist considerations such as crime prevention represent the central aim of punishment, but that particular impositions of punishment should be constrained by the familiar principles that only the criminally guilty should be punished, and only in

- Ph.D., 2011, Washington University in St. Louis. I am grateful to Richard Dagger, Larry May, Christopher Heath Wellman, and David Wood for their helpful comments on earlier drafts of this paper.

1 See, e.g., David Boonin, The Problem of Punishment 41-52 (2008); John Braithwaite \& Philit Pettit, Not Just Deserts: A Republican Theory of Criminal Justice 46 (1990); Deirdre Golash, The Case against Punishment: Retribution, Crime Prevention, and the Law 43-44 (2005); W.D. Ross, THE Right AND THE Good 56-57 (1930); H.J. McCloskey, $A n$ Examination of Restricted Utilitarianism, 66 PHIL. REv. 466, 468-69 (1957); H.J. McCloskey, Utilitarian and Retributive Punishment, 64 J. PHIL. 91, 93-102 (1967). 
proportion with the seriousness of their crimes. ${ }^{2}$ Constrained by principles such as these, deterrence as an aim of punishment looks significantly more appealing.

Even with these constraints, however, deterrence as an aim of punishment has been subject to a further line of criticism. Here, the objection is not that in some cases considerations of deterrence might permit the punishment of law abiders, but rather that punishment aimed at deterrence fails to respect offenders as autonomous moral agents-or in Kantian terms, as ends in themselves. ${ }^{3}$ This challenge is particularly powerful. It does not merely charge that deterrent punishment might allow, in certain cases, the disrespectful treatment of offenders; if this were the charge, then perhaps constraints could be articulated, similar to the constraints against punishing the innocent, to rule out such treatment. The objection here, however, is that punishment aimed at deterrence by its nature fails to treat offenders with respect. ${ }^{4}$ If the charge is valid, then additional constraints will not help. ${ }^{5}$

This paper defends deterrence as an aim (in my view, the central aim) of punishment against this objection that deterrent punishment fails to respect offenders as moral persons. I examine three prominent ways in which this charge has been fleshed out. First, some theorists, such as Jeffrie Murphy, have objected that punishing with the aim of deterrence uses the offender as a mere means to secure some social benefit, namely, crime reduction. ${ }^{6}$ The second and third versions of the objection have been developed thoroughly by R.A. Duff. A system of criminal law and punishment aimed at deterrence, Duff claims, offers reasons for compliance that are inappropriate to autonomous moral agents, and it implicitly excludes criminals from membership in the political community. ${ }^{7}$ Duff offers these as aspects of the same line of critique, ${ }^{8}$ but I argue below that they are in fact separate charges and thus merit distinct consideration. I contend that none of these objections ultimately succeeds. That is, none of them establishes that punishment aimed at deterring crime fails to demonstrate appropriate respect for persons. Specifically, a deterrent system of punishment-bounded by appropriate constraints on who may be punished and how severely — does not treat offenders as mere means to securing certain social goods, it does not offer inappropriate reasons

2 H.L.A. HART, Prolegomenon to the Principles of Punishment, in PUNISHMENT AND Responsibility: EsSays in THE Philosophy of Law 1, 8-13 (2d ed. 2008). See also Don E. Scheid, Constructing a Theory of Punishment, Desert, and the Distribution of Punishments, 10 Canadian J.L. \& JURISPRUDENCE 441, 449-50 (1997) (imposing punishments "only on offenders for their offenses and only in appropriate amounts"). For a somewhat different sort of disaggregation of the relevant questions, see Ross, supra note 1, at 61-64.

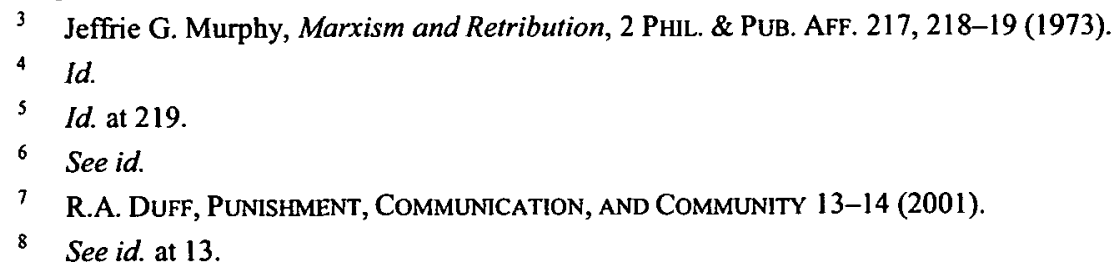


for compliance with the law, and it does not implicitly exclude criminals from membership in the political community.

In Part II, I examine and refute the objection that deterrent punishment uses offenders as mere means to securing the social goal of crime reduction. In Part III, I take a closer look at Duff's account and contend that he actually offers two distinguishable versions of the respect-based objection. In Parts IV and V, I examine each of these objections in turn, and I conclude that neither succeeds. Ultimately, deterrence is a permissible aim for a system of criminal punishment; that is, punishment aimed at deterring crime can be consistent with respect for moral persons.

\section{DOES DETERRENCE USE OFFENDERS AS MERE MEANS?}

One way to interpret the charge that deterrent punishment fails to respect offenders as persons is that such punishment appears to use offenders as mere means to deterring crime. Jeffrie Murphy, for instance, has written of deterrence that "a guilty man is, on this theory, being punished because of the instrumental value the action of punishment will have in the future. He is being used as a means to some future good-e.g., the deterrence of others." Such punishment thus appears inconsistent with maintaining proper respect for offenders as autonomous moral agents.

Murphy's characterization of the good being sought as "the deterrence of others" points to a sense in which we might think one form of deterrence can be especially problematic. ${ }^{10}$ That is, it might seem bad enough that punishment subjects offenders to hard treatment with the aim of promoting the social good of crime reduction. A critic might further point out, however, that one type of deterrence, general deterrence, seeks to achieve this social good by treating offenders in certain ways in order to affect others' behaviors, to persuade others to comply with the law. Special deterrence may also seem troubling insofar as it subjects an offender to hard treatment to bring about the social good of crime reduction, but at least it treats the offender in this manner with the aim of affecting her own future behavior, of persuading her to comply with the law in the future, rather than treating her in this way to affect others' behavior. Thus, insofar as this objection is valid, it strikes particularly hard at general deterrence.

We might respond to this line of critique by pointing out that political communities also harm law abiders for the sake of promoting some greater good. Construction of a new highway may be beneficial to the community generally, but it may harm those who live nearby (perhaps by generating noise pollution or diminishing property values). Similarly, those with a communicable disease may be forced to endure certain restrictions of their liberties in the interest of protecting

9 Murphy, supra note 3, at 219. See also BOONIN, supra note 1, at 60-61; DUFF, supra note 7 , at $13-14$

10 Murphy, supra note 3, at 219. 
public health. If harming some for the greater benefit of others is permissible in cases such as these and numerous others, then perhaps harming offenders to benefit the public by deterring crime is similarly permissible.

David Boonin rejects this line of response, however, because he believes it overlooks the distinction between intending harm and foreseeing harm. ${ }^{11}$ Boonin points out that cases such as those described above-the highway construction, or quarantining those with a communicable disease- "do not involve intentionally harming some people in order to benefit others. Rather, they involve intentionally doing acts that foreseeably cause some harm to some people and provide greater benefits to many others." ${ }^{\prime 2} \mathrm{He}$ continues:

[T]he fact is that punishment stands alone as the one instance in which the state not only does an act that predictably harms some of its citizens, but in which it acts with the explicit aim of causing harm. Punishment is utterly anomalous in this respect. This is precisely what makes punishment distinctively difficult to justify in the first place. ${ }^{13}$

Thus, for Boonin, a deterrent system of punishment is objectionable because it intentionally harms some to benefit others. The harm is the means by which the good is achieved, not merely a foreseeable consequence.

Given that the ultimate aim of a system of deterrent punishment is to reduce crime, however, I suggest that actual inflictions of punishment are not the means by which the system seeks to achieve this aim. Rather, the threat of punishment is intended to do the deterrent work. ${ }^{14}$ A deterrent system of punishment communicates a threat to everyone in the community: if you do these acts, you will be subject to punishment. Consider that if the threat of deterrent punishment were perfectly effective, no one would violate the community's laws, and thus, no one would be punished. Actual instances of punishment, then, are best seen as cases where the deterrent threat failed. ${ }^{15}$ The inflictions of harm that constitute punishment are not the means by which the good of crime reduction is achieved; rather, the means by which deterrent systems of punishment aim to reduce crime is by issuance of a threat. Obviously, in the real world, deterrent systems of punishment are not perfectly effective. Individuals continue to commit crimes

11 BOONIN, supra note 1, at 61-62.
12 Id. at 62.
13 Id. See also Nathan Hanna, Say What? A Critique of Expressive Retributivism, 27 LAw \& PHIL. 123, 124-28 (2008) (discussing hard treatment and suffering as part of the definition and essential characteristics of punishment).

14 One might worry that the threat of punishment is itself a sort of coercive sanction, in that its aim is to change incentives so that, in effect, it restricts citizens' viable options. I consider this point more below.

15 S.I. Benn noted this point. S.I. Benn, An Approach to the Problems of Punishment, 33 PhIL. 325, 330 (1958). 
despite the existence of the deterrent threat. In these cases, such individuals are harmed in the ways characteristic of punishment. But such individuals are foreseeably rather than intentionally harmed. Again, this is because the intention of a deterrent system of punishment is that everyone should take the threat seriously and avoid criminal behavior (and, in turn, punishment).

Boonin insists, however, that the intended-harm element is essential to our conception not only of deterrent punishment, but of punishment in general. ${ }^{16} \mathrm{He}$ writes:

When the state punishes someone, ... it inflicts various harmful treatments on him in order to harm him. It is not merely that in sentencing a prisoner to hard labor, for example, we foresee that he will suffer. Rather, a prisoner who is sentenced to hard labor is sentenced to hard labor so that he will suffer, and if a given form of labor turned out to be too pleasant and enjoyable, he would be sentenced to some other form of labor for precisely that reason. ${ }^{17}$

Boonin may be correct with respect to punishment whose central aim is retribution, or perhaps even special deterrence (although even on these accounts there would presumably be plausible considerations cautioning against lengthening or altering sentences once they had been issued). His point is mistaken, however, with respect to general deterrence. In a system of punishment aimed at general deterrence, sentences are not imposed to inflict suffering on the offender, but rather to maintain a credible threat to the public generally. Typically, of course, the more severe the sentence, the more the offender will suffer and the more credible the threat will be. But the concern, from the perspective of general deterrence, is not how much an offender suffers, but rather how effectively the general public is deterred from committing the given offense. In fact, if the credible threat could be maintained without harming any offenders, then this would be entirely acceptable based solely on considerations of general deterrence. ${ }^{18}$ Punishment aimed at

16 BoONIN, supra note 1 , at 12.

17 Id. at 13.

18 This point, in fact, grounds a distinct objection commonly leveled against deterrent punishments generally: insofar as the deterrent threat is what is crucial, the legal authority might be justified in some cases of merely pretending to punish offenders. This prospect is particularly troubling to those with the retributivist intuition that the guilty deserve to suffer. Advocates of deterrence as an aim of punishment might respond to this objection in various ways: they might contend that the public's likely discovery of the pretend punishment cases could undermine the general deterrent effect of the threat, or that whereas general deterrence constitutes one aim of punishment, there are others (retribution, reform, etc.) that rule out the possibility of pretending to punish. Whether these or other responses would be persuasive need not worry us here, because the question of whether general deterrence would permit pretend-punishing is a distinct one from the question of whether punishments aimed at general deterrence treat offenders as mere means. For present purposes, the relevance of the pretend-punishing objection is that it underscores that 
general deterrence, then, is best characterized not as intentionally harming some to benefit others, but rather as intentionally threatening everyone, and then foreseeably harming those who nevertheless commit crimes.

Suppose, however, that I am wrong about this. Suppose that punishment aimed at deterrence is in fact best understood as intentionally harming some to benefit others. This is still not enough to establish that such punishment would violate the Kantian principle of respect for persons. It is widely recognized that this principle does not forbid treating others as means, but as mere means. We frequently treat others as means to our own or other people's ends, and we typically consider such treatment permissible. I ask a taxi driver to take me to my destination, our country sends soldiers to fight in a war to protect our interests, or I ask a friend to lend me money. The taxi driver, the soldiers, and my friend are all treated as means to others' ends (mine, or in the case of the soldiers, the country's), but we do not find these cases objectionable as long as they are not treated merely as means. The relevant question for this version of the respect-based objection, then, is whether deterrent punishment treats offenders merely as means to the social good of crime reduction.

There are good reasons to doubt that punishing for deterrence uses offenders merely as means to the end of crime reduction. First, note that insofar as the institution of punishment yields a deterrent effect, those who commit crimes typically will have reaped benefits from the existence of this institution just as law abiders have done. Perpetrators of crime are also, like other community members, potential victims of crime. Thus, insofar as the institution of punishment helps to deter crime, it protects the safety and security of everyone.

One might respond that an offender may still be treated merely as a means when she is harmed in the interest of securing this social good, even if the social good is also a good for the offender herself. If our legal system sanctioned the occasional punishment of innocent people for the purpose of achieving the beneficial deterrent effect, for instance, then these individuals would be used as mere means even if they themselves had benefited from the deterrent effects of the institution generally. Thus, even if both offenders and law abiders enjoy the general benefits of deterrent punishment, this fact by itself appears insufficient to assure that such punishment avoids using offenders as mere means.

Deterrent punishment with prohibitions on punishing the guilty is relevantly different, however, from a system of deterrent punishment (even an overall beneficial one) that allows the punishment of the innocent. To punish law abiders would be to treat them in ways that were not responsive to choices they had actually made, and thus it would fail to respect them as autonomous moral agents. Respectful treatment requires, at least, that we treat others according to what they have actually done (or failed to do); punishing those who have violated no criminal laws fails to meet this minimal standard of respect. Notice, though, that a deterrent

punishment-as-general-deterrence aims to reduce crime not by harming offenders but rather by issuing a threat. 
system of punishment does not only offer to each community member the benefits that come from reduced crime. Deterrent punishment constrained by the retributivist principle against punishing the innocent also allows each individual to choose whether she will risk suffering the harms associated with punishment. Such a system offers everyone a choice: comply with the law, or be subject to punishment. Thus, unlike the innocent person who is punished to achieve the deterrent effect, the offender's punishment is a response to the choice she made to violate the law. Given that her punishment is a response to her own free choice, the fact that the aim of punishing her is to deter others from committing similar crimes (or her from committing similar crimes in the future) does not imply that she is treated merely as a means to this end. Hart expresses this essential idea, as he describes the institution of punishment as "offering individuals including the criminal the protection of the laws on terms which are fair, because they not only consist of a framework of reciprocal rights and duties, but because within this framework each individual is given a fair opportunity to choose" between complying with the law or facing punishment. ${ }^{19}$

Still, even if an institution of deterrent punishment offers benefits to everyone, and even if it offers each community member equally a choice about whether to endure the threatened sanction, one might still object that this choice itself is coercive, that it employs the threat of harm to restrict citizens' viable options. Richard Burgh objects to Hart's account by offering what he considers an analogous case, in which terrorists take a group of people hostage and tell each that "if he attempts to escape, he will be beaten." 20 The terrorists treat all of the hostages equally, and they stay true to their pledge to beat only those hostages who try to escape." "Simply because a hostage is given a fair opportunity to avoid being beaten," Burgh concludes, "it does not follow that his beating is just."22 Even if the terrorists "were to inform the hostages that if they do as they are told they will receive positive benefits," beating those who tried to escape would be unjust. $^{23}$ Burgh concludes that, analogously, deterrent punishment cannot be justified on grounds that it provides a choice either to comply with the law and reap benefits from others' compliance or to break the law and suffer punishment. ${ }^{24}$

Contrary to Burgh's charge, however, there is a fairly straightforward difference between the choice offered by the institution of deterrent punishment and the choice offered by the terrorists. Given that the terrorists violate each hostage's liberty rights, the hostages' choice is either not to do that which they have a moral right to do (namely, leave) or to be beaten. So the terrorists use the

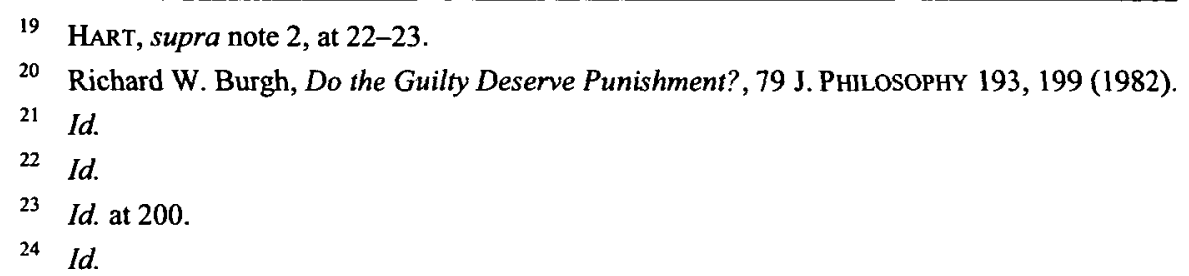


prospect of force to persuade the hostages not to do what they have a right to do. A system of deterrent punishment, however, employs the prospect of force to persuade community members not to do the sort of acts that they have a moral obligation not to do. ${ }^{25}$ Thus, the relevant question is whether a system of punishment that provides significant benefits to community members generally, and that offers a choice either not to commit acts that one has moral obligations not to commit or to be harmed, is coercive in a way that renders it inconsistent with respect for moral persons. Given that such a system offers each community member benefits, treats each according to her own choices, and seeks to persuade citizens not to do that which they have a moral obligation not to do anyway, I suggest that such a system is consistent with respecting individuals, even those punished, as autonomous moral agents.

Kant himself provides support for the view that punishment, properly constrained by the retributivist principle, may aim at deterrence while nevertheless respecting the offender. ${ }^{26} \mathrm{~A}$ criminal, he writes, "must previously have been found punishable before any thought can be given to drawing from his punishment something of use for himself or his fellow citizens."27 Although Kant's full view of punishment continues to be the subject of substantial debate, ${ }^{28}$ in this passage he suggests that deterrence is a permissible aim, which for him means that it does not use the individual as a mere means, as long as punishments are limited to those who are guilty of crimes. ${ }^{29}$

I conclude that punishment aimed at deterrence does not use offenders as mere means, and thus this version of the respect-based objection fails. Still, Kant's respect principle instructs us not only not to use others as mere means, but also to respect them as ends in themselves. ${ }^{30}$ Respecting people as ends may require more than merely not using them as mere means. Perhaps, then, there is a sense in which punishment aimed at deterrence nevertheless violates the respect principle. In the following three parts, I consider what I take to be the most thorough and compelling development of this sort of objection, by R.A. Duff.

25 This is the case, at least, when the laws backed by deterrent punishment are justified. By contrast, unjust laws (e.g., laws allowing, or requiring, what is morally prohibited) backed by deterrent punishment would be analogous to Burgh's terrorist example. As such, a system of deterrent punishment backing such laws would fail to respect those punished as moral persons.

26 See IMMANUEl KANT, THE METAPHYSICS OF MORALS (1797), reprinted in IMMANUEL KANT: PRACTICAL PhILOSOPHY 353, § 6:331, at 473 (Mary J. Gregor ed. \& trans., 1996).

27 Id.

28 See, e.g., Thom Brooks, Kant's Theory of Punishment, 15 UTILTAS 206, 208-15 (2003); Thomas E. Hill, Jr., Kant on Wrongdoing, Desert, and Punishment, 18 LAW \& PHIL. 407, 408-09 (1999); David Sussman, Shame and Punishment in Kant's Doctrine of Right, 58 PHIL. Q. 299, 30209 (2008).

29 See KANT, supra note 26, at 473.

30 See id. 


\section{DUFF'S CRITIQUE OF DETERRENCE}

R.A. Duff conceives of the criminal law as fundamentally a communicative enterprise. ${ }^{31}$ He argues that a system of punishment that aims to deter potential offenders is inappropriate for a liberal political community committed to respecting its members as members of the community. ${ }^{32}$ Essentially, this is because deterrent punishment communicates in prudential rather than moral terms:

The law of [a liberal political] community, as its common law, must address its members in terms of the values it embodies - values to which they should, as members of the community, already be committed. It portrays criminal conduct as wrongful in terms of those values; and the reasons that citizens have to refrain from such conduct, the reasons to which the law refers and on which it depends, are precisely the moral reasons that make such conduct wrong. A purely deterrent law, however, addresses those whom it seeks to deter, not in terms of the communal values that it aims to protect, but simply in the brute language of selfinterest. It thus addresses them, not as members of the normative community of citizens, but as threatening outsiders against whom the community must protect itself. It implicitly excludes them from membership of the citizen community by no longer addressing them in terms of that community's values. ${ }^{33}$

Duff is concerned, commendably, that offenders should be treated as moral persons, and in fact as continuing members of the community, rather than merely as the "['they'] against whom 'we,' the law-abiding, must protect ourselves., 34 His concern is well founded; it is all too easy, and too common, to assume that the criminal act necessarily demonstrates a criminal, perhaps even irredeemably criminal, character. Duff urges us, however, always to regard the person guilty of a criminal offense as nevertheless one of us, a member of our community who may come to share (or recommit to) the moral values that the community endorses. ${ }^{35}$ Despite the significant virtues of Duff's account, however, I contend that his objection to punishments aimed at deterrence misses its mark. There is a real sense in which a system of punishment aimed at deterring crime (with appropriate constraints) can nevertheless demonstrate appropriate respect for criminal offenders, and thus avoid being objectionably exclusionary.

Note that Duff actually offers two critiques of systems of punishment aimed at deterrence- two ways in which such systems of punishment fail to treat
31 DuFf, supra note 7, at 79
32 Id. at 78.
33 Id. at 78-79.
$34 \quad I d$. at 78.
35 Id. 
individuals with appropriate respect as autonomous moral agents. First, deterrent punishment offers individuals the wrong sort of reasons to comply with the law. It offers merely prudential reasons to comply-i.e., to avoid incarceration, community service, etc.-rather than the appropriate moral reasons-i.e., that the prohibited acts are morally condemned by the community. Second, by offering merely prudential reasons, rather than making the sort of moral appeal that is appropriate to members of a liberal political community, a deterrent system of punishment implicitly excludes those it addresses from membership in the community. It fails to respect them as fellow community members who, as members, share (or should share, and can come to share) the community's moral values. Punishing to deter is thus exclusionary, Duff believes, in that it reinforces the distinction between "us," the law-abiding citizens, and "them," the criminals, rather than treating offenders as continuing to be fellow members of our community.

Duff implies that the second critique follows from the first. That is, he indicates that a system of punishment aimed at deterrence excludes certain individuals from the political community because it offers them the wrong sort of reasons (i.e., prudential reasons) to comply with the law. ${ }^{36}$ In fact, however, these are distinct critiques. The charge that deterrent punishment is exclusionary rests on the notion that it treats offenders differently from law abiders. It perpetuates the distinction between "us" (the law abiders) and "them" (the criminals) and implicitly excludes "them" from the community in which "we," as law abiders, are still included as members. By contrast, the objection that punishment aimed at deterrence provides the wrong sort of reasons to comply with the law does not depend on its offering different reasons to offenders and to law abiders. Rather, a system of punishment might offer the same inappropriate reasons for compliance to everyone. As such, it would not treat one group (offenders) as less a part of the political community than another group (law abiders). It would not perpetuate the objectionable "we" and "they" distinction, because such a system would communicate the same message, and offer the same reasons, to everyone. ${ }^{37}$ Thus, whereas one objection contends that deterrent punishment offers the wrong sort of reasons, the other contends that such punishment inappropriately offers different reasons to different members of the community.

I suggest, then, that these two critiques warrant distinct consideration. We should ask, first, if punishment aimed at deterrence communicates a different message to (or provides different reasons to, or in some other way excludes)

36 Id. at 78-79.

37 One might respond that such a system of punishment would then be exclusionary of everyone. But if everyone is excluded, then we must ask, excluded from what? Duff's point is that deterrent punishments exclude offenders from their communities, but if all community members (law abider and offender alike) were excluded, then it is not clear what community would remain for those excluded to be excluded from. Thus, central to the charge that deterrent punishment excludes certain community members is the claim that it treats some (the excluded) differently from others (the included). 
criminals from the political community generally; and second, if the reasons such a system of punishment offers for complying with the law are themselves the wrong sort of reasons to offer fellow members of the political community. I consider each of these critiques in turn and contend that, ultimately, each fails. A system of punishment aimed at deterrence communicates the same message to everyone in the political community. Thus it does not implicitly exclude anyone. Furthermore, a deterrent system of punishment is compatible with demonstrating appropriate respect to all members of the community as members who share (or should share, and can come to share) the community's fundamental moral values.

\section{IS DETERRENT PUNISHMENT EXCLUSIONARY?}

The first objection evident in Duff's account is that a system of punishment aimed solely at deterrence implicitly excludes offenders from their community. It treats offenders as the "they" against whom "we," the law-abiding members of the community, must protect ourselves. Thus it fails to treat offenders with appropriate respect. Given Duff's conception of the criminal law as a fundamentally communicative enterprise ${ }^{38}$ the worry with deterrent punishment is that, insofar as it offers the offender only prudential reasons why she should not have committed, say, theft or tax evasion, it fails to communicate with her as (still) a member of the community. A more appropriate message to a community member would appeal to the moral reasons that her act was wrong, namely, that such acts violate important moral values that the community shares (and thus that she, as a member of the community, should also share).

The thrust of the "exclusion" objection to deterrent punishment, then, is that once a member of the community commits a crime, the criminal law stops talking to her as it talks to law abiders, to whom it offers appropriate, moral reasons not to violate the law. Instead, it begins to talk with her in the language of mere prudence, as though this is the only language she is capable of understanding. As such, it inappropriately excludes her from membership in her community.

One might understandably be tempted to respond here that the offender, in committing her crime, essentially excludes herself from membership in the community-or at least, that she demonstrates that she does not share the community's moral values. If so, then it may seem appropriate for a system of punishment to communicate to her solely in the language of prudence rather than in the language of the community's moral values. Duff rejects this argument, however, for several reasons, the most persuasive of which is that it is empirically dubious. ${ }^{39}$ Often, criminal acts are not evidence that offenders have no regard for the community's moral values, but rather

\footnotetext{
38 DuFf, supra note 7 , at 79

39 Id. at 84.
} 
[T] hat their regard is not wholehearted, or consistent, or always sufficient to overcome the temptations of self-interest. They-or rather we, since these comments surely apply to many of us-are not wholly deaf to the law's moral appeal, though we do not attend to it consistently or carefully enough. ${ }^{40}$

Duff is right to caution against assuming that an individual's criminal act is evidence of a complete rejection, or lack of regard, for the community's values.

There is a more fundamental problem, however, with the claim that deterrent punishment somehow communicates to offenders differently from law abiders, and thus excludes offenders from the political community. The message communicated by a system of punishment aimed at deterrence essentially takes the form of a threat: if you commit some criminal act, then you will be liable to having some form of suffering inflicted on you. It is important to consider, however, to whom this message is communicated. For deterrent punishment to be exclusionary, to create the sort of "we-they" dichotomy that concerns Duff, it would have to be the case that a system of deterrent punishment communicates one (prudential) message only to criminal offenders, and that law abiders, by contrast, receive another (moral) appeal that is appropriate to members of the political community.

But this is doubly wrong. First, a system of deterrent punishment communicates its prudential message, its threat, to everyone. For those who have not committed a crime, the prospect of punishment offers reasons not to do so (i.e., it acts as a general deterrent). For those who do commit crimes, their punishments - or more specifically, the unpleasant prospect of another term of punishment in the future-provide reasons not to recidivate (i.e., they act as a special deterrent). From the perspective of deterrent punishment, then, everyone is a potential offender (or reoffender), and such a system of punishment communicates the same prudential message to everyone. Therefore, and secondly, if law abiders receive the moral appeal that Duff believes is appropriate to members of the political community, the source of this appeal is not the system of deterrent punishment. Rather, the moral appeal must come from somewhere else, such as, perhaps, the criminal laws themselves. But if it is the criminal laws that communicate the moral message, that declare certain actions to be morally condemned by the community, the intended audience of this communication is everyone, law abider and offender alike. Thus, it is not the case that, in receiving the prudential message of a deterrent system of punishment, offenders are treated differently from others in the community, who are exclusive recipients of the moral message. It appears that deterrent punishment is not essentially exclusionary in the way Duff indicates.

There are other ways, of course, in which existing penal practices tend to exclude offenders from the community. Imprisonment, by its nature, removes 
offenders physically from the larger community. Beyond this, prisoners are typically excluded from participation in the political process, most obviously by being denied the vote. ${ }^{41}$ Also, offenders are excluded from access to basic financial services (bank accounts, credit, insurance), not only during their incarceration but often, in practice, even after their release. ${ }^{42}$ These and other forms of exclusion should be troubling to members of a liberal political community who are concerned to treat individuals, even offenders, with respect as autonomous moral agents. But notice that such forms of exclusion are not distinctively characteristic of systems of punishment aimed at deterrence (and constrained in the ways suggested earlier). Because punishment involves the restriction of offenders' liberties in ways that law abiders' liberties are not restricted, issues of exclusion will always arise. But such issues are not distinctive of systems of punishment aimed at deterrence. Rather than communicating differently to offenders and law abiders, and thus perpetuating the "we-they" distinction that concerns Duff, systems of punishment aimed at deterrence regard everyone equally as potential offenders. They communicate the same message, namely, if you commit a crime, then you will be liable to being harmed. I conclude, then, that punishment aimed at deterrence is not exclusionary as Duff charges.

\section{DOES DETERRENT PUNISHMENT OFFER THE WRONG SORT OF REASONS FOR COMPLIANCE?}

Given that deterrent punishment communicates the same reasons to everyone, the question then becomes whether these reasons are appropriate. Duff contends that they are not. He writes, "The criminal law of a liberal polity, and the criminal process of trial and conviction to which offenders are subjected, are communicative enterprises that address the citizens, as rational moral agents, in the normative language of the community's values." ${ }^{, 43}$ Additionally, the institution of punishment, a constitutive element of the institution of criminal law generally, must similarly communicate in moral rather than prudential terms. A system of punishment aimed at deterring criminals, however, aims to secure general compliance with the law by means of a threat, rather than by moral appeal. Thus, Hegel famously objected: "To base a justification of punishment on threat is to

41 In the United States, only Maine and Vermont allow incarcerated felons to vote. The Sentencing Project Interactive Map, THE SENTENCING PROJECT, http://www.sentencingproject.org/map/map.cfm (last visited Nov. 19, 2010). A number of states go further than this, imposing a lifetime voting ban on anyone with a felony conviction, even those who have served their sentences. See id.

42 Gaynor Pengelly, Give Prisoners Bank Accounts, THIS Is MONEY (Oct. 25, 2010), http://www.thisismoney.co.uk/savings-and-banking/article.html?in_article_id=517136\&in_page_id 7\&position=moretopstories. For a fuller discussion of types of exclusion, see DUFF, supra note 7 , at $75-77$.

43 DuFf, supra note 7, at 80 . 
liken it to the act of a man who lifts his stick to a dog. It is to treat a man like a dog instead of with the freedom and respect due to him as a man."44 Like Hegel, Duff worries that the prudential terms in which deterrent punishment communicates with community members, the prudential reasons it gives them to comply with the community's laws, are not the sort of reasons that are appropriate to offer to autonomous members of a liberal political community, who endorse (or could come to endorse) the community's moral values. ${ }^{45}$

I offer a couple of responses to this worry. First, punishment may communicate a prudential message to community members without communicating a solely prudential message. In my view, the good of punishment, the reason we should want such an institution, is that it plays a key role in ensuring the well-being of community members. Thus, the proper aim of punishment is to prevent or reduce crime by offering potential wrongdoers reasons not to offend. Punishment may serve this aim by supplying potential offenders with prudential reasons not to offend (reasons such as the desire to avoid the harms characteristic of incarceration, etc.), but it may also provide moral reasons. As is commonly recognized, punishment involves not only what Joel Feinberg called a "hard treatment" aspect but also an expressive aspect in that punishment expresses the community's condemnation of the offender for her criminal act. ${ }^{46}$ Even before the commission of a crime, however, the threat of punishment also expresses the community's condemnation not of a particular offender but rather of the offense itself. If a potential offender receives and accepts this message of condemnation, it may play a role in persuading her not to do what she otherwise would have done. If so, then even if the fear of punitive suffering also played a role in dissuading her, I suggest that she is treated with the respect due to her as a moral person. Thus, even if a system of punishment's central aim is to provide prudential reasons for compliance, this does not preclude its also providing moral reasons.

Second, even if a system of punishment did provide solely prudential reasons to comply with the law, this does not show that the criminal legal system more generally fails to communicate with community members as moral persons. I agree with Duff that the criminal law should appeal to citizens as moral agents who share (or should share, and can come to share) the community's values. But punishment is only one aspect of the criminal legal system. Suppose we grant, then, that a community through its criminal statutes declares certain acts to be wrong and makes a moral appeal to community members to comply, whereas trials and convictions communicate a message of deserved moral censure to the wrongdoer and urge the wrongdoer "to understand and accept the censure as justified." ${ }^{, 47}$ Why, then, must punishment also make a moral appeal? Why is it

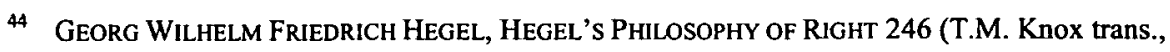
1942).

45 DuFf, supra note 7 , at 80.

46 JOEL FEINBERG, The Expressive Function of Punishment, 49 MONIST 397, 397-423 (1965).

47 DuFF, supra note 7, at 80 .
} 
inappropriate for the institution of punishment to communicate a solely prudential message?

First, one might argue that the criminal legal system must be univocal in the message it communicates to community members, and that this message must be a moral rather than a prudential one. Thus, the institution of punishment, as one element of the criminal law generally, must communicate a moral message. It is not clear why this should be so, however. We can grant, with Duff, that the criminal legal institution should communicate a moral message to community members while still: (a) recognizing that distinct elements of the institution can communicate different messages; (b) maintaining that the criminal statutes themselves, and perhaps the process of trial and conviction, sufficiently communicate the moral message; and thus, (c) denying that punishment must communicate this same message. Notice, too, that if the entire criminal legal system must be univocal in its moral message, much more than deterrent punishment would be prohibited. The practice of plea bargaining, for one, would appear unjustifiable if prudential appeals were inappropriate in criminal law. More reasonable, I suggest, is to claim that the criminal law should address community members in moral terms, and in fact that the moral message should be central, but that as long as this moral message is present, prudential appeals also have an appropriate role.

A second possible response is that whereas the criminal law need not, in principle, communicate only a moral message, the prudential message of deterrent punishment is inappropriate in practice because it tends to drown out the moral message. That is, perhaps the threat of punishment is so powerful that it tends to focus community members' attention on the prudential reasons not to commit crimes and causes them to lose sight of the moral appeal. Andrew von Hirsch, who conceives of punishment as offering prudential reasons to supplement the (sometimes insufficiently motivating) moral reasons supplied by the criminal law, advocates a "decremental strategy" according to which prescribed sentences would be reduced gradually to levels at which the prudential reasons they offered would not drown out the moral reasons for compliance with the laws. ${ }^{48}$ Duff is skeptical of such a strategy, however, as he believes that sentences mild enough so as not to overwhelm the moral message with the prudential threat would be too mild to achieve much deterrent effect at all. ${ }^{49}$ By contrast, sentences sufficiently severe to provide any genuine deterrent effect would replace, rather than merely supplement, the moral appeal. ${ }^{50}$

I suggest that this worry, that the prudential appeal of deterrent punishment may drown out the moral message of the criminal law generally, inaccurately depicts the relationship of the moral and prudential appeals. Rather than accepting that a stronger prudential message will tend to weaken the moral message

\footnotetext{
48 Andrew von HiRsch, Censure and Sanctions 36-46 (1993).

49 DuFf, supra note 7 , at 88.

so Id.
} 
comparatively, why not acknowledge that the prudential threat actually can reinforce the moral appeal? Granted, an institution of punishment aimed at deterrence provides prudential reasons to comply with the community's laws. But the existence of such an institution also invites us to consider, or remind ourselves, why our community believes that these laws, and the interests they protect, are of sufficient moral weight that we are willing to invoke the threat of hard treatment to help ensure that they are not violated. Rather than drowning out the moral message of the criminal law, as Duff fears-the message that certain acts are prohibited because society regards them as significant moral violations-deterrent punishment can reinforce this message, as it underscores that protecting community members from such violations is sufficiently important to warrant the infliction of harm as a response.

The prudential message of deterrent punishment, therefore, is compatible with the criminal law's communication of a moral appeal to community members, and thus with respecting them as autonomous moral agents. On one hand, a system of punishment aimed at deterrence may nevertheless provide moral as well as prudential reasons for compliance. On the other hand, even if punishment itself provides only prudential reasons, the criminal legal system need not be univocal. As long as the moral message is communicated prominently (by the laws themselves and the process of trial and conviction), respect for persons does not require that the institution of punishment communicate in moral terms. I conclude, then, that this third articulation of the respect-based objection fails.

\section{CONCLUSION}

In closing, it is worth emphasizing again the scope of the defense of deterrence that I have offered here. Specifically, I have not aimed to defend deterrence as sufficient to ground a complete justification of punishment. Rather, my focus has been on deterrence as the aim of punishment, constrained by certain considerations such as the retributivist principles against punishing the innocent or excessively punishing the guilty. Critics of deterrence, such as Murphy and Duff, claim that even as one element of this sort of hybrid account of punishment, deterrence is objectionable because it fails to treat individuals with appropriate respect as autonomous moral agents. I have contended, however, that on what I take to be the three most plausible articulations of this critique, it nonetheless fails. Constrained in certain ways, then, I conclude that deterrence is a permissible aim of punishment. 